\title{
Clinical isolated syndrome mimicking focal brainstem glioma in a child
}

\author{
Brandon C Gabel, ${ }_{1}^{1}$ Janet Yoon, ${ }^{2}$ John Ross Crawford ${ }^{1,2}$
}

${ }^{1}$ Department of Neurosurgery, University of California San Diego, San Diego, California, USA

${ }^{2}$ Department of Pediatrics, University of California San Diego, San Diego, California, USA

\section{Correspondence to}

Dr John Ross Crawford, jrcrawford@ucsd.edu

Accepted 20 February 2014

\section{DESCRIPTION}

A 5-year-old boy presented to our hospital with a 10-day history of progressive left-sided facial weakness, drooling and inability to swallow in the absence of a preceding febrile illness. Two weeks prior to presentation he had been camping with his family. Neurological examination revealed left facial palsy, left palatal weakness, depressed gag reflex and mild left-sided hypoglossal weakness. MRI of the brain demonstrated a focal contrast enhancing lesion in the left medulla that was T2 hyperintense without surrounding vasogenic oedema (figure 1A,B). Lumbar puncture revealed normal glucose, protein and no pleocytosis or abnormal cytology. A comprehensive laboratory and serological workup for infectious aetiologies was negative as was MRI of the spine. The child was placed on dexamethasone for 7 days with marked improvement in his symptoms and MRI. Given the clinical and radiographic improvement, a biopsy was not performed and clinical isolated syndrome was considered the most likely diagnosis. At 3 years of follow-up his MRI shows no evidence of abnormality (figure 1C,D) and neurological examination reveals only mild left-sided palatal weakness.

The differential diagnosis of focal brainstem lesions of childhood includes infectious,

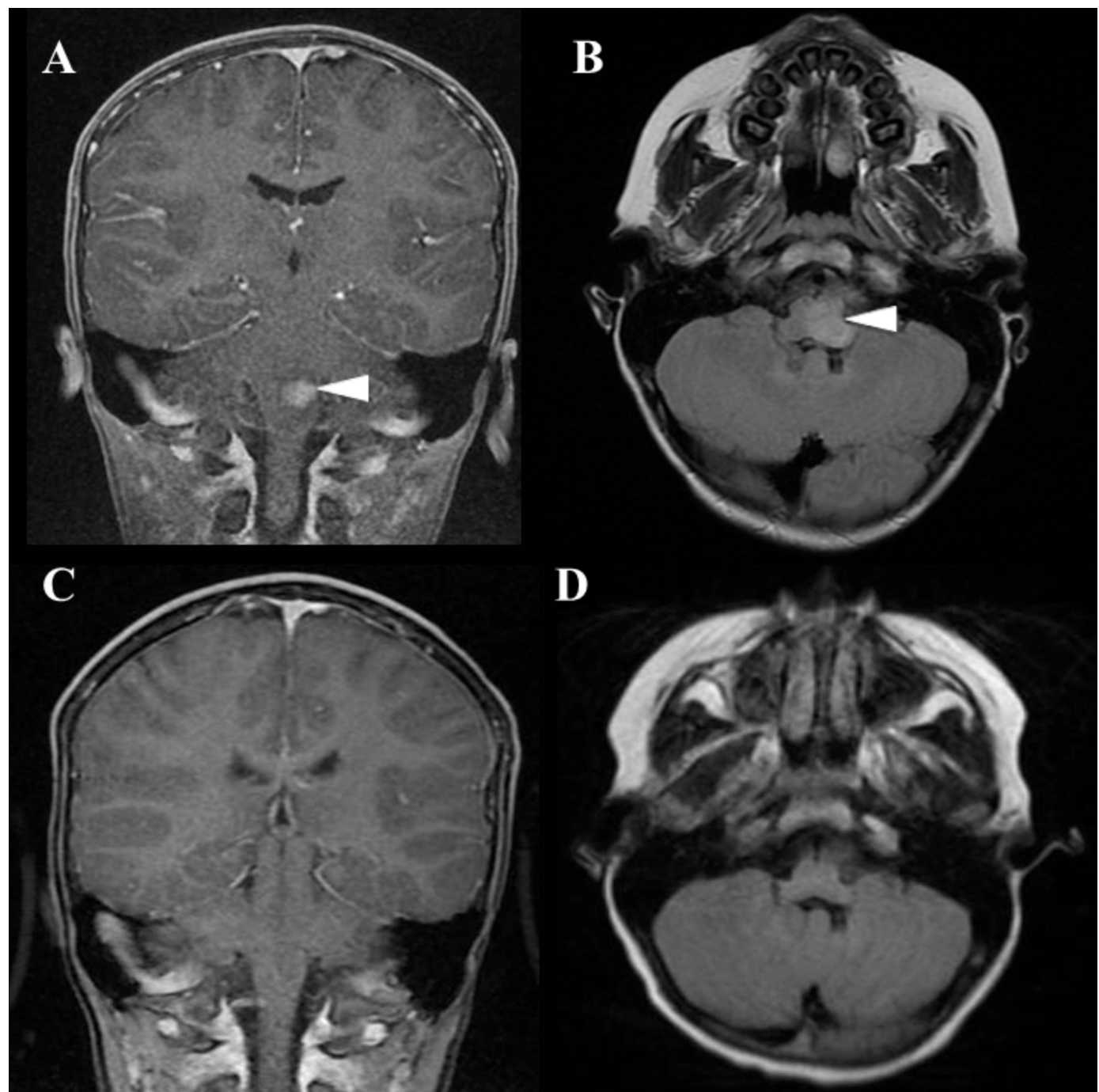

Figure $1 \mathrm{MRI}$ at presentation ( $\mathrm{A}$ and $\mathrm{B}$ ) reveals a contrast-enhancing focal lesion in the medulla $(\mathrm{A})$ that is hyperintense on axial fluid-attenuated inversion recovery sequence (B). MRI at 3 years postpresentation (C and D) demonstrates resolution of the lesion. 


\section{Learning points}

- Clinical isolated syndrome and acute disseminated encephalomyelitis may be indistinguishable from neoplasm on MRI and should be considered in the differential diagnosis of focal brainstem lesions.

- Clinical observation followed by a short interval MRI may be appropriate in certain clinical settings that would obviate the need for diagnostic biopsy in the absence of progression.

postinfectious, vascular and neoplastic causes. Tuberculosis, syphilis and amoebic abscess have all been reported as mimicking focal brainstem glioma. ${ }^{1-3}$ Diagnostic considerations for focal brainstem tumours in this age group would include lowgrade glial tumours or rarely central nervous system lymphoma.
Our case highlights that clinical isolated syndrome may mimic a focal brainstem glioma obviating a biopsy in certain clinical situations.

Contributors $B C G, J Y$ and JRC have contributed equally to the writing of the manuscript. All authors have reviewed and approved the contents.

Competing interests None.

Patient consent Obtained.

Provenance and peer review Not commissioned; externally peer reviewed.

\section{REFERENCES}

1 Ventura N, Cannelas R, Bizzo B, et al. Intracranial syphilitic gumma mimicking a brain stem glioma. Am J Neuroradiol 2012;33:E110-11.

2 Lowichik A, Rollins N, Delgado $R$, et al. Leptomyxid amebic meningoencephalitis mimicking brain stem glioma. Am J Neuroradiol 1995;16:926-9.

3 Del Brutto $\mathrm{OH}$, Mosquera A. Brainstem tuberculoma mimicking glioma: the role of antituberculous drugs as a diagnostic tool. Neurology 1999;52:210-11.

Copyright 2014 BMJ Publishing Group. All rights reserved. For permission to reuse any of this content visit

http://group.bmj.com/group/rights-licensing/permissions.

BMJ Case Report Fellows may re-use this article for personal use and teaching without any further permission.

Become a Fellow of BMJ Case Reports today and you can:

- Submit as many cases as you like

- Enjoy fast sympathetic peer review and rapid publication of accepted articles

- Access all the published articles

- Re-use any of the published material for personal use and teaching without further permission

For information on Institutional Fellowships contact consortiasales@bmjgroup.com

Visit casereports.bmj.com for more articles like this and to become a Fellow 